NOTE

\title{
Zostera marina seagrass beds enhance the attachment of the invasive alga Sargassum muticum in soft sediments
}

\author{
James R. Tweedley, Emma L. Jackson, Martin J. Attrill* \\ Marine Biology \& Ecology Research Centre, Marine Institute \& School of Biological Sciences, University of Plymouth, \\ Drake Circus, Plymouth PL4 8AA, UK
}

\begin{abstract}
The first reports of Sargassum muticum occurring in British waters coincided with a warning that this invasive alga may replace seagrass beds, particularly those of Zostera marina. Initial fears were allayed when subsequent research suggested that both species required different attachment substrata, and, therefore, $S$. muticum would be unable to replace Zostera beds on soft sediments. Here, however, we present evidence supporting the original warning: contrary to previous research we found that $S$. muticum is able to successfully colonise soft sediments and, furthermore, that the presence of $Z$. marina may aid attachment. The majority of $S$. muticum plants within Zostera beds studied at Salcombe, SW England, were found attached within the soft sediment; outside of the seagrass bed, however, this occurred in greatly reduced numbers. Therefore, we suggest that the presence of $Z$. marina may actually enhance $S$. muticum colonization of soft sediments, trapping drifting fragments and allowing viable algae to settle on the seagrass matrix in an otherwise unfavorable environment. The consequences for the invasion of seagrass beds by $S$. muticum may therefore be more severe than previously thought.
\end{abstract}

KEY WORDS: Sargassum muticum · Seagrass · Invasive alga · Zostera marina · Soft sediment Resale or republication not permitted without written consent of the publisher

\section{INTRODUCTION}

In 1973, concerns were first raised about the possible ecological effects of the introduced Japanese seaweed Sargassum muticum (Yendo) Fensholt, when Druehl (1973) suggested that $S$. muticum may displace seagrass beds. His evidence was based on observations in British Columbia that the alga had become well established in sheltered low intertidal and shallow subtidal waters, a position usually occupied by the eelgrass Zostera marina L. Zostera spp. provide a large range of ecosystem services (Jackson et al. 2001); for example, they are an important nursery habitat for juvenile fish and have been shown to harbour a larger number of individuals and species than surrounding areas (Mattila et al. 1999, Polte et al. 2005, Pihl et al. 2006), so such replacement would have wide ecological consequences. North (1973) disputed the concerns of Druehl
(1973) after examining $S$. muticum patches in California, where he claimed that the alga requires a solid substrate for attachment. With $Z$. marina occurring solely on soft sediments, he concluded that, in California, the 2 species coexist without apparent competition, thus allaying fears that $S$. muticum may replace $Z$. marina. Subsequent studies on $S$. muticum also reported that the alga requires a hard substrate, e.g. bedrock, boulders, stones or solid man-made structures (Fletcher \& Fletcher 1975, Norton 1977), while small stones ( $<10 \mathrm{~cm}$ in diameter), gravel and sand are considered unsuitable substrata (Thomsen et al. 2006). A study by den Hartog (1997) attempted to answer the question 'Is Sargassum muticum a threat to eelgrass beds?' He similarly concluded that due to the contrasting substratum preferences, the beds of the 2 species would remain well separated. He reported, however, that although $S$. muticum was not able to invade closed 
Z. marina beds on soft substrata, the alga was able to replace $Z$. marina in littoral pools with mixed substratum containing sand, gravel, stones, and shell grit.

During other seagrass ecology studies, we observed Sargassum muticum occurring within a Zostera bed (defined as a monospecific bed of the species $Z$. marina) in the Salcombe-Kingsbridge estuary (Devon, SW England), contrary to the conclusion of bed separation by den Hartog (1997). Therefore, the aim of this study was to investigate the attachment mechanism and growth of $S$. muticum within and outside seagrass beds at Salcombe to assess the significance of this observation. We investigated 2 questions: (1) can Sargassum muticum successfully attach on soft substrata, and (2) can $Z$. marina enhance this attachment?

\section{MATERIALS AND METHODS}

Study site. Sampling of Sargassum muticum plants occurred within Castle Bay $\left(50^{\circ} 23^{\prime} \mathrm{N}, 03^{\circ} 77^{\prime} \mathrm{W}\right)$ of the Salcombe-Kingsbridge Estuary in Devon, SW England (Fig. 1). The system is termed a 'ria', a fairly sheltered

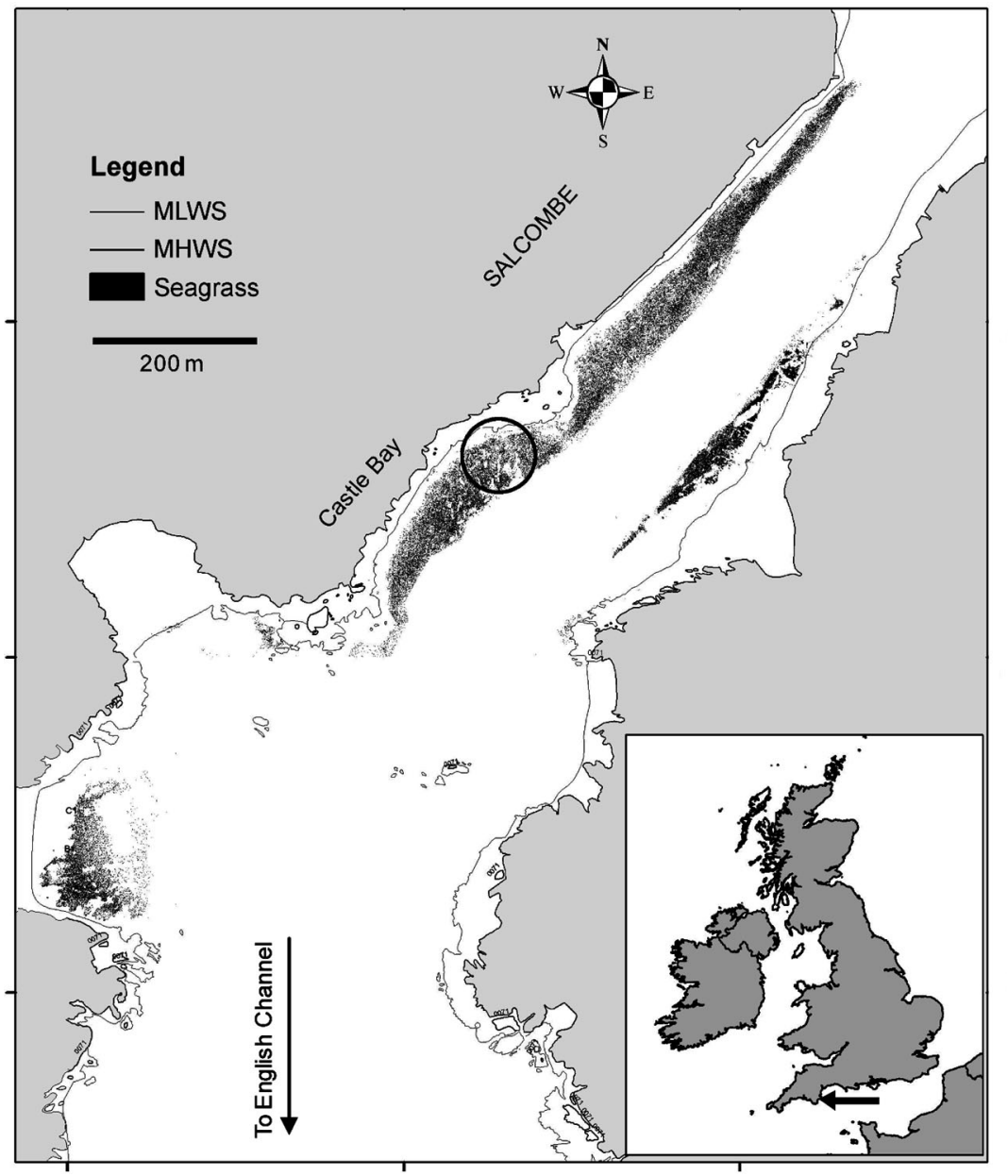

drowned river valley with minimal freshwater input producing salinities of around 34 to 35 . The shores are gently sloping with a maximum width of $12.5 \mathrm{~m}$. Tides are semi-diurnal with a mean tidal range of 4.6 and $2.0 \mathrm{~m}$ at spring and neap tides respectively. Total seagrass extent within the estuary is estimated at 6.3 ha, with 2 ha occurring within Castle Bay (Fig. 1); shoot density averages 240 shoots $\mathrm{m}^{-2}$. S. muticum has been present in Devon since 1976 (Boalch \& Potts 1977).

Sampling procedure. During a low tide in March 2006, the attachment substratum of Sargassum muticum plants growing in Castle Bay was investigated. The location of each plant was recorded (within or outside the Zostera bed, with outside the Zostera bed being termed 'Sargassum bed'). In order to record the attachment substratum of plants growing within the soft sediment accurately, specimens were dug up, the sediment rinsed away carefully, and the buried section examined. The attachment substratum was classified as either hard (i.e. visible stones, pebbles) or soft (i.e. sand/mud with no evidence of holdfasts attached to hard objects). Eight samples of sediment were taken from within each bed type to assess overall differences in the sediment structure between Zostera and Sargassum beds, in particular, the availability of pebbles for settlement. Sediment analysis was undertaken using a Malvern Long-bed Mastersizer X laser particle sizer. The total length of the plant, from the bottom of the holdfast (if present) to the top of the longest primary lateral of each specimen was then recorded. When holdfasts were absent from plants buried in soft sediment, length was measured from the base of the plant.

Statistical analysis. Chi-square analysis was performed to identify any relationship between the location of Sargassum muticum plants and their attachment substratum. Due to very small n-values for $S$. muticum plants growing on hard substrata within seagrass beds, a formal balanced 2-way ANOVA was not suitable. Differences between the length of $S$. muticum plants at each location and on each sub-

Fig. 1. Salcombe-Kingsbridge Estuary, Devon, England. Circle indicates the precise sampling location and the shaded area the location of seagrass beds. MLWS: mean low water springs; MHWS: mean high water springs 
stratum were therefore compared using $t$-tests in order to maximize n-values within each category, but correcting the alpha level to 0.025 to account for multiple tests. Prior to analysis, data were tested for normality and homogeneity of variance using Anderson-Darling and Bartlett's tests respectively. In all cases, the assumptions of normality and homogeneity were met, thus allowing the use of parametric tests. For testing differences in sediment particle size, non-parametric Mann-Whitney $U$-tests were used to accommodate the percentage data.

\section{RESULTS}

There was no significant difference between available sediments within Sargassum and Zostera beds (Mann-Whitney $U$-test: $Z=-1.846, \mathrm{p}>0.05$ ) in terms of the percentage of pebbles available in each area for S. muticum attachment (Sargassum: 1.92 to $66.51 \%$; Zostera: 0.16 to $66.07 \%)$. Median particle sizes were different, however $(Z=-2.216, \mathrm{p}<0.05)$, due to larger amounts of finer particles in the seagrass bed, as would be expected.

In total, 110 Sargassum muticum plants were sampled, of which 77 occurred outside the Zostera bed and 33 inside. Of the 77 within the Sargassum bed, 75\% were attached to hard substrate; conversely, within the Zostera bed, $91 \%$ of the plants were attached to the soft substratum. Chi-square analysis of plant densities on the 2 substrata between bed types (Fig. 2a) proved significant $\left(\chi^{2}=41.02, \mathrm{p}<0.001\right)$.

The mean length $( \pm \mathrm{SE})$ of Sargassum muticum plants was $40.59 \pm 2.69 \mathrm{~cm}$ in Sargassum beds and $37.43 \pm 2.73 \mathrm{~cm}$ in Zostera beds, respectively (Fig. 2b), which proved to be non-significant ( $t$-test: $t=0.67, \mathrm{p}=$ 0.416), indicating that the location of the alga in relation to the Zostera bed had no significant effect on the length of the $S$. muticum plant. A significant difference was observed, however, when comparing the mean length of $S$. muticum plants on different substrates, with plants attached to hard substrata having a mean length of $41.93 \pm 2.71 \mathrm{~cm}$ compared to $14.67 \pm 3.28 \mathrm{~cm}$ when attached to soft substrate ( $t$-test: $t=6.41, \mathrm{p}<$ 0.001 ), thus indicating that the type of attachment substrate may influence the size of the plant.

\section{DISCUSSION}

The observations of Sargassum muticum growing in soft substrata presented here are, to the best of our knowledge, the only report to date of $S$. muticum growing in soft substrata without hard attachment. Virtually all other research indicates that $S$. muticum

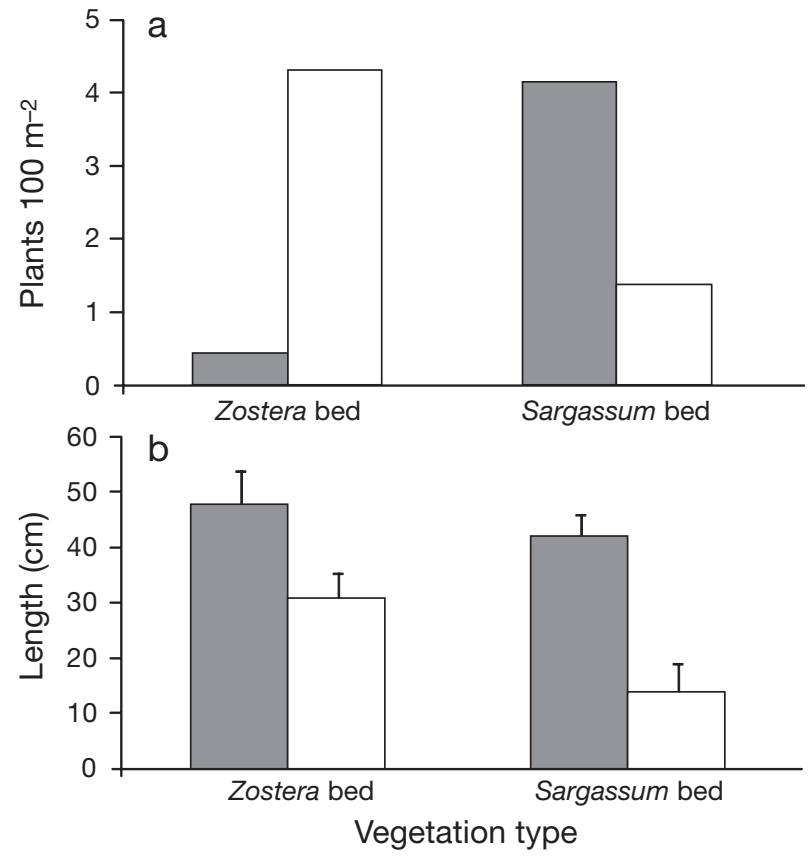

Fig. 2. Sargassum muticum. (a) Density of plants either attached to hard substrata or buried in soft substratum in both Zostera and Sargassum beds (chi-square: $\chi^{2}=41.02, \mathrm{p}=$ $<0.001 ; \mathrm{n}=110)$. (b) Mean length $( \pm \mathrm{SE})$ of plants in different substrata and vegetation types (see text for n-values and analyses). Grey bars: hard substratum, white bars: soft substratum

prefers a hard substrate (North 1973, Fletcher \& Fletcher 1975, Norton 1977). Thomsen et al. (2006) even correlated the abundance of $S$. muticum with the presence of hard substrate $>10 \mathrm{~cm}$ in diameter. The only report to state that $S$. muticum may grow in a mixed substratum was den Hartog (1997), who reported that $S$. muticum may occur in areas containing sand, gravel, and stones. However, if the plants were attached to stones in a mixed substratum, the attachment would be via the holdfast. In the soft substrate of Castle Bay, Salcombe, some $S$. muticum plants were devoid of a holdfast and in others the holdfast was not attached to any form of hard substrate (rock, stone, shell, etc.), but instead was buried, with the weight of sand around the holdfast and primary lateral providing the attachment. The plants attached to hard substrata via a holdfast were most likely either plants that had grown from a germling or plants transported to the Bay via 'stonewalking', where plants attached to small stones may become buoyant and dispersed by local currents (Critchley 1983b).

Norton (1983) investigated the resistance to dislodgement of Sargassum muticum germlings under different hydrographic conditions. He concluded that germling survival was positively correlated with substratum roughness up to an optimum rugosity where 
the mean depth of depression was $420 \mu \mathrm{m}$ and the vast majority of depressions were deeper than the height of the germlings. Germlings of $S$. muticum have an area of $400 \mu^{2}$ (Steen \& Rueness 2004), and therefore will be unlikely to settle in Castle Bay as the average grain size within the Zostera marina beds is $159 \mu \mathrm{m}$; any that may manage to settle will have insufficient support for further growth. Also, Morrell \& Farnham (1982) reported that $S$. muticum is more susceptible to tissue loss due to sand abrasion than Ulva spp., again suggesting that $S$. muticum is unlikely to successfully settle in sandy substrates.

It is suggested here that Sargassum plants occupying the soft substrate had therefore not grown from germlings, but are vegetative material detached from older plants that may have become caught up in the seagrass bed. Norton (1981) showed that detached floating material is viable for up to 3 months, and that it may become fertile during this time. Sediment is deposited in macrophyte beds due to their capacity to reduce current velocities and attenuate wave energy (Grady 1981, Gambi et al. 1990). Therefore, if detached vegetative material from $S$. muticum plants washed up in a Zostera bed, then deposition of sediment onto the bed may bury the basal part of the plant within the rhizome mat, providing a secure attachment within the substratum. Morrell \& Farnham (1982) reported $S$. muticum to be far more resistant to burial than Laminaria digitata, and it even decayed slower than control specimens submersed in filtered seawater and kept in the dark. They suggested that burial initiates some self-protective response from the plant. To date, 18 species belonging to the genus Sargassum, including S. muticum (Withers et al. 1975, Gorham \& Lewey 1984), are known to produce tannins and other antibiotic substances (Conover \& Sieburth 1964, Stiger et al. 2004). These substances inhibit microflora and epibionts (Sieburth \& Conover 1965, Ryland 1974) and so could conceivably inhibit microbial degradation of the below-ground Sargassum biomass when parts of the plants become buried in the Zostera bed, providing the self-protective response that Morrell \& Farnham (1982) suggested. This response, together with a secure attachment point, could provide $S$. muticum plants with a suitable habitat in which to grow. Although the base of the alga would be buried, the plant is not in danger of total burial, as growth rates of $S$. muticum primary laterals growing in the Solent (Southern England) averaged 1 to $2 \mathrm{~cm} \mathrm{~d}^{-1}$ and may increase up to $4 \mathrm{~cm} \mathrm{~d}^{-1}$ between May and June (Davidson 1999), indicating that the alga would grow faster than the sediment deposition rate. In addition, the axil of leaf lamina on all laterals contains air bladders, providing positive buoyancy and thus keeping the laterals from being buried.
Significant differences were found, however, between the lengths of Sargassum muticum plants growing in the different substrata, with plants attached to hard substrata being longer. One possible reason for this may be that larger plants become buoyant and break free from their attachment from within the rhizome mat or sediment of the Zostera bed. As discussed, the plants provide enough buoyancy that at times they are able to lift the hard substrate they are attached to, a phenomenon know as 'stonewalking' (see Critchley 1983b). Therefore, it is conceivable that larger, more buoyant plants may become detached during turbulent hydrographic conditions, thus leaving only the smaller, less buoyant plants buried in the soft sediment (Critchley 1983b).

No significant difference was found between the lengths of Sargassum muticum plants attached to similar substrata in different vegetation types, indicating that it is the substratum that dominates the growth of the plant and not the surrounding conditions. This is consistent with the work of North (1973), Norton (1977) and den Hartog (1997), who stated that the plant can coexist with Zostera marina without any apparent direct competition. However, this does not mean there is not any competition, and these results only show that at Castle Bay the mean length of $S$. muticum plants remained consistent regardless of the surrounding vegetation. As $S$. muticum is an opportunistic species and rapidly colonises any free space (Critchley 1983a), it is therefore potentially in indirect competition with $Z$. marina. After S. muticum settles in an area previously colonised by $Z$. marina, it can interfere with the regeneration of the bed; no germlings of $Z$. marina have been found in $S$. muticum stands (den Hartog 1997). This is similar to reports of competition between S. muticum and the giant kelp Macrocystis pyrifera, where once $S$. muticum has settled it prevents reestablishment of the indigenous $M$. pyrifera (Ambrose \& Nelson 1982).

\section{CONCLUSIONS}

This study demonstrates that the presence of Zostera beds may enhance the settlement of Sargassum muticum plants, allowing the alga to settle in an otherwise sub-optimal substratum. Rather alarmingly, den Hartog (1997) forecast that 'in time one may expect that $S$. muticum will replace the eelgrass ( $Z$. marina) bed'. His prediction, however, was based on a decline in the Zostera beds due to disease, environmental and anthropogenic effects rather than just interactions with $S$. muticum. If the presence of $S$. muticum attached within Zostera beds shown in the study is found to occur in other locations, it is possible that the predic- 
tion made by den Hartog (1997) may occur more rapidly than previously thought. Further research is needed into this area before any conclusions can be drawn, with more sites sampled to see if $S$. muticum's ability to settle in soft sediment is prevalent just within the Salcombe-Kingsbridge Estuary due to any topographic, hydrographic and climatic conditions, or whether this phenomenon occurs elsewhere.

Acknowledgements. We thank N. Mortimer (Marine Conservation Officer, South Hams District Council) and L. Heape (Natural England) for continuing support of seagrass ecology work at Salcombe. We also thank R. Ticehurst, P. Goumenaki, C. Goswell, S. Mowles, S. Glanfield and A. Torr for their help when conducting fieldwork and P. Goumenaki for providing sediment analysis data.

\section{LITERATURE CITED}

Ambrose RF, Nelson BV (1982) Inhibition of giant kelp recruitment by an introduced brown alga. Bot Mar 25: 265-267

Boalch GT, Potts GW (1977) The first occurrence of Sargassum muticum (Yendo) Fensholt in the Plymouth area. J Mar Biol Assoc UK 57:29-31

Conover JT, Sieburth JMcN (1964) Effects of Sargassum distribution on its epibiota and antibacterial activity. Bot Mar 6:147-157

Critchley AT (1983a) The establishment and increase of Sargassum muticum (Yendo) Fensholt population within the Solent area of Southern Britain. I. An investigation of the increase in number of population individuals. Bot Mar 26: 539-545

Critchley AT (1983b) The establishment and increase of Sargassum muticum (Yendo) Fensholt populations within the Solent area of southern Britian. II. An investigation of the increase in canopy cover of the alga at low water. Bot Mar 26:547-552

Davison DM (1999) Sargassum muticum in Strangford Lough, 1995-1998: a review of the introduction and colonisation of Strangford Lough MNR and CSAC by the invasive brown algae Sargassum muticum. Environment and Heritage Service Research and Development Series 99/27

den Hartog C (1997) Is Sargassum muticum a threat to eelgrass beds? Aquat Bot 58:37-41

Druehl LD (1973) Marine transplantations. Science 179:12

Fletcher RL, Fletcher SM (1975) Studies on the recently introduced brown alga Sargassum muticum (Yendo) Fensholt. I. Ecology and reproduction. Bot Mar 18:149-156

Gambi MC, Nowell ARM, Jumars PA (1990) Flume observations on flow dynamics in Zostera marina (eelgrass) beds. Mar Ecol Prog Ser 61:159-169

Editorial responsibility: Victor de Jonge,

Haren, The Netherlands
Gorham J, Lewey SA (1984) Seasonal changes in the chemical composition of Sargassum muticum. Mar Biol 80: 103-107

Grady JR (1981) Properties of sea grass and sand flat sediments from the intertidal zone of St. Andrew Bay, Florida. Estuaries 4:335-344

Jackson EL, Rowden AA, Attrill MJ, Bossey SJ, Jones MB (2001) The importance of seagrass beds as a habitat for fishery species. Oceanogr Mar Biol 39:269-303

Mattila J, Chaplin G, Eilers MR, Heck KL, O'Neal JP, Valentine JF (1999) Spatial and diurnal distribution of invertebrate and fish fauna of a Zostera marina bed and nearby unvegetated sediments in Damariscotta River, Maine (USA). J Sea Res 41:321-332

Morrell SL, Farnham WF (1982) Some effects of substratum on Sargassum muticum. Br Phycol J 17:236-237

North WJ (1973) Regulating marine transplantation. Science 179:1181

Norton TA (1977) Ecological experiments with Sargassum muticum. J Mar Biol Assoc UK 57:33-43

Norton TA (1981) The varied dispersal mechanisms of an invasive seaweed, Sargassum muticum. Phycologica 20: 110-111

Norton TA (1983) The resistance to dislodgement of Sargassum muticum germlings under defined hydrodynamic conditions. J Mar Biol Assoc UK 63:181-193

Pihl L, Baden S, Kautsky N, Rönnbäck P, Söderqvist T, Troell $M$, Wennhage H (2006) Shift in fish assemblage structure due to loss of seagrass Zostera marina habitats in Sweden. Estuar Coast Shelf Sci 67:123-132

Polte P, Schanz A, Asmus H (2005) The contribution of seagrass beds (Zostera noltii) to the function of tidal flats as a juvenile habitat for dominant, mobile epibenthos in the Wadden Sea. Mar Biol 147:813-822

Ryland JS (1974) Observations on some epibionts of gulfweed, Sargassum natans (L.) Meyen. J Exp Mar Biol Ecol 14:17-25

Sieburth JMcN, Conover JT (1965) Sargassum tannin, an antibiotic which retards fouling. Nature 208:52-53

Steen H, Rueness J (2004) Comparison of survival and growth in germlings of six fucoid species (Fucales: Phaeophyceae) at two different temperatures and nutrient levels. Sarsia 89:175-183

Stiger V, Deslandes E, Claude EP (2004) Phenolic contents of two brown algae, Turbinaria ornate and Sargassum mangarevense on Tahiti (French Polynesia): interspecific, ontogenic and spatio-temporal variations. Bot Mar 47: 402-409

Thomsen MS, Wernberg T, Stæhr PA, Pedersen MF (2006) Spatio-temporal distribution patterns of the invasive macroalga Sargassum muticum within a Danish Sargassum bed. Helgol Mar Res 60:50-58

Withers RG, Farnham WF, Lewey S, Jephson NA, Haythorn JM, Gray PWG (1975) The epibonts of Sargassum muticum in British waters. Mar Biol 31:79-86

Submitted: February 28, 2007; Accepted: September 3, 2007

Proofs received from author(s): January 8, 2008 